\title{
GERAKAN PEMBARUAN HUKUM LiNGKUNGAN INDONESIA DAN PerWujudan TATA Kelola Lingkungan Yang BaiK DALAM NEGARA DEMOKRASI
}

\author{
Mas Achmad Santosa \\ Margaretha Quina
}

\begin{abstract}
Abstrak
Gerakan pembaruan hukum lingkungan ('GPHL') mendorong perwujudan tata kelola lingkungan hidup yang baik, rule of law, dan demokrasi. Berbagai hasil advokasi yang dilakukan oleh gerakan ini terekam dalam perangkat hukum, regulasi dan kebijakan nasional dan internasional, putusan hakim, sampai dengan inisiatif-inisiatif masyarakat sipil. Artikel ini akan mengidentifikasi perkembangan-perkembangan penting yang telah dicapai hukum lingkungan dan kontribusi masyarakat sipil, akademisi, maupun unsur lain yang terkait sebagai bahan acuan pengembangan tata kelola lingkungan kedepannya.
\end{abstract}

Kata kunci: pembaruan hukum lingkungan, kaleidoskop hukum lingkungan, demokrasi dan hukum lingkungan

\section{Abstract}

Environmental law reform movement promotes the realization of good environmental governance, rule of law, and democracy. Numerous advocacy results conducted by this movement has been recorded in the legal instruments, national and international regulation and policies, landmark judges decision, until civil society initiatives. This article will identify the important developments and the contribution of civil society, academics, and other related elements as a reference for the further development of good environmental governance.

Keywords: environmental law reform, environmental law kaleidoscope, democracy and environmental law 


\section{Pendahuluan}

Hukum lingkungan Indonesia telah berkembang pesat selama empat dekade terakhir. ${ }^{1}$ Sebagian besar perkembangan tersebut merupakan respon atas pengaruh hukum lingkungan internasional, yang terhubung erat dengan pengaruh perkembangan ilmu pengetahuan dan biaya ekonomi. ${ }^{2}$ Beberapa penelitian mengindikasikan bahwa bentuk pemerintahan yang demokratis dapat meningkatkan kualitas lingkungan hidup melalui perwujudan tata kelola lingkungan yang baik. ${ }^{3}$

Forum for Democratic Reform mengidentifikasi elemen-elemen kunci kemajuan demokrasi: 1) Reformasi Negara dan Institusinya, yang mencakup otoritas sipil dan angkatan bersenjata, struktur ekonomi dan tata kelola korporasi, demokratisasi dan desentralisasi; 2) Rule of Law, yang mencakup constitutional review dan reformasi pemilihan umum; 3) Budaya demokratis, yang mencakup pluralisme keagamaan dan koeksistensi damai, peran advokasi dan monitoring dari organisasi masyarakat sipil (civil society organizations atau 'CSO'), dan partisipasi perempuan dalam politik. ${ }^{4}$

Pembaruan hukum lingkungan tidak terlepas dari rule of law sebagai salah satu elemen kunci dari demokrasi. Dalam konteks rule of law lima hal

${ }_{1}$ Penelitian ini mengambil titik awal perkembangan hukum lingkungan Indonesia semenjak Konferensi Stockholm pada 1972, yang beriringan dengan cikal bakal berdirinya Kementerian Lingkungan Hidup. Sekalipun demikian, pengaturan mengenai lingkungan hidup secara formal sebenarnya telah dimulai semenjak zaman Kolonial dalam peraturanperaturan mengenai perikanan, yang dapat dilihat di antaranya sejak 1916 dalam Parelvisscherij, Sponsenvisscherijordonnantie (Stbl. 1916 No. 157) yang mengatur jarak pemanfaatan, Visscherijordonnantie (Stbl. 1920 No. 396) yang melindungi keadaan ikan tangkapan, serta Hinder Ordonantie (Stbl. 1940 No. 450) yang masih berlaku hingga sekarang. Pengaturan yang berdimensi konservasi dan tata ruang juga telah bertumbuh pada masa ini. Lih: Koesnadi Hardjasoemantri, Hukum Tata Lingkungan Cet. ke-17, Ed. ke-7, (Yogyakarta: Gajah Mada University Press, 2002), hlm. 57-60.

2 Phillipe Sands menjelaskan bahwa hukum lingkungan internasional sangat dipengaruhi oleh berbagai faktor non-legal, dengan dua faktor yang paling berpengaruh adalah pengaruh perkembangan ilmu pengetahuan dan biaya ekonomi. Dalam konteks Hukum Lingkungan Internasional, beberapa faktor lain adalah: meningkatnya keperdulian masyarakat, konsepsi keadilan penanggulangan permasalahan lingkungan antar negara, serta keuntungan politik jangka pendek. Lih: Phillipe Sands, Principles of International Environmental Law, $2^{\text {nd }}$ Edition, (Cambridge: Cambridge University Press, 2003), hlm. 6-7.

3 Quan Li dan Rafael Reuveny, "Democracy and Environmental Degradation", International Studies Quarterly (2006) 50, 935-956

4 Forum for Democratic Reform, Democratization in Indonesia: An Assessment, (Stockholm: International Institute for Democracy and Electoral Assistance, 2000), hlm. 13. 
berikut adalah elemen kunci: 1) Kepastian hukum; 2) Peradilan yang independen ; 3) Penegakan hukum yang efektif; 4) Pembentukan peraturan perundang-undangan yang partisipatif; 5) Akses terhadap keadilan, terutama bagi masyarakat yang termarginalkan dan tidak beruntung.

Jika hubungan antara demokrasi dan tata kelola lingkungan yang baik dimaknai sebagai peningkatan partisipasi masyarakat dan penguatan akses terhadap keadilan dalam pengelolaan lingkungan hidup, ${ }^{5}$ maka menilik kembali gerakan pembaruan hukum lingkungan di Indonesia dapat menjadi titik tolak dalam memahami peran masyarakat dalam struktur hukum lingkungan sekarang ini.

Dapat dikatakan perwujudan partisipasi masyarakat dalam demokrasi dipengaruhi oleh teori Christoper Stone mengenai hak objek-objek alam (natural objects), yang pada intinya mendalilkan bahwa lingkungan perlu memiliki wali (guardian) - merupakan pengakuan atas hak intrinsik lingkungan hidup dimana manusia ditunjuk sebagai wali dalam menjalankan hak tersebut. ${ }^{6}$ Dalam hal ini, teori Stone paling tampak dalam perwujudan akses terhadap keadilan, yang di Indonesia diwujudkan dalam NGO Standing. Senada dengan teori ini adalah Sierra Club v. Morton, yang merupakan salah satu kasus landmark dalam perlindungan lingkungan di mana salah satu hakimnya, William O. Douglas, mengajukan dissenting opinion yang sangat monumental, ${ }^{7}$

"[...] So it should be as respects valleys, alpine meadows, rivers, lakes, estuaries, beaches, ridges, groves of trees, swampland, or even air that feels the destructive pressures of modern technology and modern life. The river, for example, is the living symbol of all the life it sustains or nourishes - fish, aquatic insects, water ouzels, otter, fisher, deer, elk, bear, and all other animals, including man, who are dependent on it or who enjoy it for its sight, its sound, or its life. The river as plaintiff speaks for the ecological unit of life that is part of it. Those people who have a meaningful relation to that body of water - whether it be a fisherman, a canoeist, a

5 Mas Achmad Santosa, "Peran Reformasi Hukum dalam Mewujudkan Good Environmental Governance," dalam Good Governance dan Hukum Lingkungan, (Jakarta, ICEL: 2001), hlm. 116.

${ }^{6}$ Christopher Stone, Should Trees Have Standing? Law, Morality and the Environment, 3rd ed. (London: Oxford University Press, 2010). Lihat juga: Christopher Stone, 'Should Trees Have Standing' (1972) 45 S. California Law Review 450

7 Susan R. Schrepfer, "Establishing Administrative 'Standing': The Sierra Club and the Forest Service, 1897-1956", The Pacific Historical Review, Vol. 58, No. 1, 1989, hlm. 55-81 
zoologist, or a logger - must be able to speak for the values which the river represents and which are threatened with destruction [...]

The voice of the inanimate object, therefore, should not be stilled,' 8

Dissenting opinion tersebut kemudian memicu diskursus secara meluas di berbagai negara dalam hal penegasan hak bagi lingkungan hidup dan/atau sumber daya alam untuk memiliki kedudukan hukum dalam mempertahankan perlindungan dirinya sendiri.

St. Munadjat Danusaputro, Guru Besar hukum lingkungan pertama di Indonesia, berkontribusi cukup besar dalam mengkontekstualisasikan pemikiran-pemikiran hukum lingkungan dalam konteks Indonesia serta menstrukturkan hukum lingkungan secara akademis. Pengaruh pemikirannya terutama tampak dalam perkembangan awal hukum lingkungan di Indonesia, di antaranya dengan memisahkan hukum lingkungan Indonesia ke dalam dua bagian, yaitu pra-kemerdekaan dan pasca-kemerdekaan; ${ }^{9}$ serta mengadopsi pembedaan sectoral dan general environmental law dengan penegasan karakter pembeda yang tercermin dalam konteks Indonesia. Selain dalam legislasi dan administrasi, ia juga melandaskan perspektif hukum lingkungan dalam geopolitik nasional melalui gagasan wawasan nusantara, serta meletakkan perspektif lingkungan dalam konteks kedaulatan melalui gagasan archipelagic state. $^{10}$

Pemikir lain yang sangat berpengaruh dalam perkembangan hukum lingkungan Indonesia adalah Koesnadi Hardjasoemantri, terutama dalam hal peran serta masyarakat dalam pengambilan keputusan lingkungan. ${ }^{11}$ Pemikirannya yang paling menonjol dan relevan dengan tata kelola lingkungan hidup yang baik dalam demokrasi adalah dalam hal pentingnya peran serta masyarakat dalam pengambilan keputusan terkait lingkungan hidup dan SDA.

${ }^{8}$ Kasus ini merupakan gugatan yang mendalilkan hak gugat lingkungan hidup yang pertama, di mana Sierra Club menggugat US Forest Service atas kerugian lingkungan hidup yang disebabkan pembangunan Mineral King di dekat Sequoia National Park. Sekalipun Pengadilan mendalilkan bahwa Sierra Club tidak memiliki kapasitas, namun diakui sebuah kapasitas hukum individu yang dapat menggugat atas dasar kepentingan estetik ataupun rekreasionalnya. Lih: Sierra Club v. Morton 405 U.S. 727 (1972)

9 St. Munadjat Danusaputro, Hukum Lingkungan, Buku 1: Umum, (Jakarta: Binacipta, 1981). Lih. juga: St. Munadjat Danusaputro, Environmental Education and Training: Supporting Programme for the Development of Environmental Law, (Jakarta: Binacipta, 1981)

10 St. Munadjat Danusaputro, Hukum lingkungan: Hukum Lingkungan Nusantara (Dalam Sistem Nasional dan Internasional), Buku V, Jilid 2, (Bandung: Binacipta, 1984)

11 Pemikiran Koesnadi terutama terlihat dalam UU Lingkungan Hidup 1982, bersama dengan Emil Salim, Mochtar Kusumaatmadja, dan Otto Soemarwoto. 
Prof. Koesnadi berpendapat bahwa peran serta masyarakat akan memberikan informasi yang berharga bagi para pengambil keputusan, dan akan mereduksi kemungkinan resistensi masyarakat. Dengan diperhatikannya keberatankeberatan yang diajukan dalam proses pembuatan keputusan, kemungkinan pengajuan perkara dapat diminimalisir dan perlindungan hukum dapat terjadi. ${ }^{12}$ Secara spesifik, Prof. Koesnadi telah mendalilkan perlu dipenuhinya beberapa syarat agar peran masyarakat menjadi efektif dan berdaya guna. ${ }^{13}$ Lebih dari itu, secara nyata Prof. Koesnadi berkontribusi sangat besar dalam mewujudnyatakan pemikiran tersebut dengan melibatkan organisasi masyarakat sipil (civil society organization - 'CSO') dalam pembentukan kebijakan-kebijakan lingkungan hidup. Prof. Koesnadi pula yang memprakarsai peningkatan kapasitas CSO dalam pengembangan hukum lingkungan di Indonesia, sehingga keterlibatan masyarakat sipil menjadi lebih kuat.

Teori hukum pembangunan yang dicetuskan Mochtar Kusumaatmadja juga cukup berpengaruh. ${ }^{14}$ Dengan menekankan pada "hukum sebagai sarana penertiban masyarakat" - ketertiban dan keteraturan sebagai tujuan pembangunan dan pembaruan, paradigma ini mengadopsi positivisme dengan

12 Koesnadi Hardjasoemantri, Environmental Legislation in Indonesia, (Yogyakarta, Indonesia: Gadjah Mada University Press, 1987).

13 Syarat-syarat tersebut adalah: (1) Pemastian penerimaan informasi dengan mewajibkan pemrakarsa kegiatan mengumumkan rencana kegiatannya. (2) Informasi Lintasbatas (transfortier information); mengingat masalah lingkungan tidak mengenal batas wilayah yang dibuat manusia, maka ada kemungkinan kerusakan lingkungan di satu daerah akan pula mempengaruhi propinsi atau negara tetangga. Sehingga pertukaran informasi dan pengawasan yang melibatkan daerah-daerah terkait menjadi penting; (3) Informasi tepat waktu (timely information); suatu proses peran serta masyarakat yang efektif memerlukan informasi yang sedini dan seteliti mungkin, sebelum keputusan terakhir diambil. Sehingga, masih ada kesempatan untuk memeprtimbangkan dan mengusulkan altenatif-alternatif pilihan; (4) Informasi yang lengkap dan menyeluruh(comprehensive information); walau isi dari suatu informasi akan berbeda tergantumg keperluan bentuk kegiatan yang direncanakan, tetapi pada intinya informasi itu haruslah menjabarkan rencana kegitana secara rinci termasuk alternatif-alternatif lain yang dapat diambil (5) Informasi yang dapat dipahami (comprehensive information); seringkali pengambilan keputusan di bidang lingkungan meliputi masalah yang rumit, kompleks dan bersifat teknis ilmiah, sehingga haruslah diusahakan informasi tersebut mudah dipahami oleh masyarakat awam. Lih: Ibid.

14 Pemikiran Mochtar Kusumaatmadja diadopsi dan dikembangkan sebagai landasan filsafat hukum dari pembangunan hukum nasional sejak tahun 1973 sebagaimana dapat disimak dalam GBHN 1973-1983. Elaborasi lebih detail mengenai teori ini Lih: Mochtar Kusumaatmadja, Fungsi dan Perkembangan Hukum dalam Pembangunan Nasional, (Bandung: Bina Cipta), hlm. 2-13. 
kepastian hukumnya. ${ }^{15}$ Di sisi lain, teori ini juga mendalilkan hukum sebagai alat pengatur atau sarana pembangunan, dalam arti penyalur arah kegiatan masyarakat yang dikehendaki ke arah pembaharuan. ${ }^{16}$ Penormaan pembangunan, termasuk pula hukum lingkungan, berada di depan masyarakat, sebagaimana pemikiran ini secara parsial berakar pada pemikiran Rescoe Pound, yang menyatakan hukum sebagai "a tool of social engineering" yang bertindak sebagai alat pembaharuan dalam masyarakat yang diharapkan dapat berperan mengubah nilai-nilai sosial dalam masyarakat. ${ }^{17}$ Dalam hal ini, perwujudan demokrasi tampak dari penegakan hukum (rule of law) yang berwawasan lingkungan.

Paradigma lingkungan hidup dalam pembangunan di awal perkembangannya banyak dipengaruhi oleh keterlibatan Emil Salim dalam Bruntland Commission (World Commission on Environment and Development 'WCED'). Pasca WCED, Ia mulai merintis perkembangan lingkungan hidup dimulai dengan memimpin Panitia Perumus dan Rencana Kerja Bagi Pemerintah di Bidang Lingkungan Hidup, yang disusul oleh persiapan RUU Lingkungan Hidup dan berdirinya Kementerian yang membidangi lingkungan hidup. ${ }^{18}$ Kedekatan Emil Salim dengan organisasi masyarakat sipil dan akademisi menyebabkan adanya ciri khusus dalam perkembangan awal pemerintahan bidang lingkungan hidup dalam awal perkembangannya, yaitu kerja sama dan pemikiran yang menyeluruh dari berbagai pemegang kepentingan - terutama CSO dan akademisi. Hal ini pun terlihat jelas dalam pengembangan hukum lingkungan Indonesia, di mana UU No. 4 Tahun 1982 yang merupakan UU pertama yang berfungsi sebagai general environmental law melibatkan masyarakat luas dalam penyusunannya.

15 Ibid.

16 Dalam konsepsi ini, hukum yang memadai tidak cukup berupa kaidah dan asasasas yang mengatur kehidupan manusia dalam masyarakat, tetapi harus pula mencakup lembaga (institution) dan proses (processes) yang diperlukan untuk mewujudkan hukum itu dalam kenyataan. Lih: Mochtar Kusumaatmadja, Hukum, Masyarakat, dan Pembinaan Hukum Nasional, (Bandung: Binacipta, 1995), hlm. 13.

17 Lih: Rescoe Pond, Social Control Through Law, (New Brunswick: Yale University Press, 2006). Beberapa pemikiran lain yang mempengaruhi teori hukum pembangunan Mochtar adalah natural law, positivisme hukum, mahzab Savigny, sociological jurisprudence, pragmatic legal realism, Marxist jurisprudence, dan anthropological jurisprudence. Untuk elaborasi lebih mendalam, Lih: Otje Salman, Ikhtisar Filsafat Hukum, (Bandung: Armico, 1987), hlm. 1217

18 Kementerian Lingkungan Hidup, Sejarah Kementerian Lingkungan Hidup, Sumber: http://www.menlh.go.id/tentang-kami/sejarah-klh/ 
Dalam skala global, menarik pula menilik pandangan Vandana Shiva mengenai earth democracy yang dikemukakan pada 2005,

'Earth democracy dalam konteks kontemporer merefleksikan nilainilai, pandangan-pandangan dunia, dan aksi-aksi dari berbagai gerakan yang bekerja untuk kedamaian, keadilan, dan keberlanjutan. Kombinasi dari demokrasi representatif dan globalisasi ekonomi telah melahirkan ketakutan-ketakutan baru, kekhawatiran-kekhawatiran baru, fundamentalisme baru, dan kekerasan yang baru,'19

Ia menguraikan sepuluh prinsip earth democracy, yang sekalipun tergolong mewakili paham deep ecology, dapat dianalisis untuk dilihat dalam konteks pengembangan hukum lingkungan Indonesia. Prinsip-prinsip tersebut mencakup nilai intrinsik dari setiap spesies, keanekaragaman dan interkoneksi bumi, hingga 'living economy' dan 'economic democracy'. ${ }^{20}$

Untuk merefleksikan peranan pembaruan hukum lingkungan Indonesia dalam mewujudkan tata kelola lingkungan yang baik dalam demokrasi ini, Penulis merunut kembali peristiwa-peristiwa sejarah yang mempengaruhi perkembangan hukum lingkungan, baik dalam skala global maupun nasional atau domestik. Setidaknya, terdapat empat kelompok besar dari peristiwa ini, yaitu: (1) Peristiwa internasional dan perjanjian internasional; (2) Kebijakan, peraturan perundang-undangan, dan peraturan lainnya di level nasional; (3) Landmark cases atau yurisprudensi; serta (4) Inisiatif masyarakat sipil atau donor.

\subsection{Pengaruh Global: Peristiwa dan Perjanjian Internasional}

Kesadaran global mengenai lingkungan hidup, terutama dalam aspek pengendalian pencemaran seiring dengan ditulisnya Silent Spring oleh Rachel

${ }_{19}$ Vandana Shiva, Earth Democracy: Justice, Sustainablity, and Peace, (Cambridge: South End Press, 2005), hlm. 7 - 11.

20 1) Nilai intrinsik dari setiap spesies, manusia, dan budaya; 2) Komunitas bumi sebagai demokrasi dari semua kehidupan; 3) Harus dipertahankannya keanekaragaman budaya dan alam; 4) Hak natural semua kehidupan untuk lestari; 5) Berlandaskan 'living economy' dan 'economic democracy'; 6) Living economies dibangun di atas ekonomi lokal; 7) Earth democracy adalah living democracy; 8) Earth democracy dilandaskan pada living culture; 9) Living culture yang berkarakter 'life nourishing'; 10) Earth democracy mengglobalkan kedamaian, perhatian, dan kasih. Lih: Ibid, hlm. $10-11$. 
Carson, ${ }^{21}$ memicu pertumbuhan yang sangat pesat gerakan lingkungan hidup pada 1960-an di Amerika Serikat dan Eropa, ternyata belum memunculkan reaksi cukup kuat dalam diskurus hukum lingkungan di Indonesia. Pemikiran mengenai lingkungan hidup mulai mengarusutama di Indonesia pasca Stockholm Declaration on Human Environment pada 1972, yang menandai kesepakatan global pertama mengenai pentingnya lingkungan hidup bagi manusia $^{22}$ yang menghasilkan tujuan-tujuan kebijakan lingkungan hidup yang luas. ${ }^{23}$ Salah satu efek lanjutan penting dari Stockholm adalah penormaan perlindungan lingkungan hidup sebagai hak, dikenal pula sebagai rights to environment, yang mengenal beberapa pendekatan dan cakupan, baik substantif maupun prosedural. ${ }^{24}$ Pada 1980an, hubungan antara HAM dan lingkungan hidup yang diakui dalam Stockholm Declaration dikristalkan dalam perjanjianperjanjian internasional yang mengikat, 25 diikuti ribuan instrumen soft law terkait lingkungan hidup internasional, puluhan konstitusi nasional dan perundang-undangan legislatif, serta lusinan putusan badan peradilan internasional, regional, maupun nasional yang memperkuat keberadaan hak asasi manusia atas lingkungan hidup ini. ${ }^{26}$

21 Silent Spring yang menjelaskan mengenai dampak polusi yang disebabkan oleh industri agrikultur pada rantai makanan menandai lahirnya gerakan lingkungan hidup di AS yang diikuti oleh kesadaran global mengenai lingkungan. Lihat: Rachel Carson, Silent Spring, (Boston: Houghton Mifflin, 1962)

22 United Nations, Report of the U.N. Conference on the Human Environment, Declaration of the U.N. Conference on the Human Environment, U.N.Doc.A/CONF. 48/14 /Rev. 1,p. 3 (June 5 16,1972 )

${ }^{23}$ Günther Handl, UN Audiovisual Library of International Law: Declaration Of The United Nations Conference On The Human Environment (Stockholm Declaration), 1972 And The Rio Declaration On Environment And Development, 1992, hlm. 1

${ }^{24}$ Luis E. Rodriguez-Rivera melihat doktrin rights to environment mencakup right of environment, yaitu hak intrinsik lingkungan hidup, right to environment yang berdimensi substantif, termasuk hak-hak asasi lain yang pemenuhannya bergantung pada lingkungan hidup yang baik dan sehat, serta environmental rights yaitu aspek prosedural. Lih: Luis E. Rodriguez-Rivera, "Is The Human Right To Environment Recognized Under International Law? It Depends on the Source", Colorado Journal of International Environmental Law and Policy, Vol. 12, (Winter 2001), hlm. 4.

${ }^{25}$ Lih: The African Charter on Human Rights, diadopsi di Nairobi, Kenya, on June 27, 1981, Additional Protocol to the American Convention on Human Rights in the Area of Economic, Social, and Cultural Rights, O.A.S.T.S. 69, dicetak ulang dalam International Legal Materials Vol. 28, (1989), hlm. 156.

${ }^{26}$ Luis E. Rodriguez-Rivera, Op.Cit., hlm. 23. 
Bruntland Commission ${ }^{27}$ yang menghasilkan laporan Our Common Future $^{28}$ pada 1987 merupakan langkah selanjutnya dari Stockholm. Dokumen laporan ini sendiri, yang dikenal pula sebagai Bruntland Report, meletakkan proposal prinsip-prinsip hukum untuk perlindungan lingkungan dan pembangunan berkelanjutan. ${ }^{29}$ Selanjutnya, dokumen ini menjadi landasan bagi Earth Summit dan perumusan Agenda 21. Kontribusi utama dari Bruntland Report ini terhadap konsepsi pembangunan berkelanjutan mencakup pengakuan berbagai banyak krisis yang dihadapi planet bumi merupakan krisis yang saling terkait dan merupakan elemen dari satu krisis secara keseluruhan.

Di tahun 1992, Earth Summit di Rio de Janeiro menandai kesepakatan global mengenai hubungan lingkungan hidup dengan pembangunan, dengan perspektif lingkungan hidup dari negara maju dan representasi pembangunan, ketidaksetaraan global, dan hubungannya dengan lingkungan hidup bagi negara berkembang. ${ }^{30}$ Dalam Konferensi ini, diadopsi tiga dokumen penting dalam perkembangan hukum lingkungan ke depannya: (1) Rio Declaration on Environment and Development, sebuah dokumen soft law yang kemudian menjadi rujukan dari berbagai perjanjian internasional dan beberapa prinsipnya kemudian mengkristal dan diakui sebagai kebiasaan internasional; (2) United Nations Framework Convention on Climate Change (UNFCCC), yang diratifikasi Indonesia melalui UU Nomor 6 Tahun 1994;31 United Nations Convention on Biodiversity (UNCBD) yang juga diadopsi Indonesia, melalui UU Nomor 5

${ }^{27}$ World Commission on Environment and Development (WCED) atau lebih dikenal sebagai Bruntland Commission, mulai bertugas pada akhir 1983. Our Common Future dihasilkan pada 1987, merupakan dokumen pertama yang secara global memperkenalkan dan mendefinisikan terminologi "sustainable development" (pembangunan berkelanjutan). Lih:

${ }^{28}$ Development And International Economic Co-Operation: Environment, Report of the World Commission on Environment and Development, diadopsi oleh UN General Assembly dengan Resolusi No: A/42/427, pada tanggal 4 August 1987

29 Our Common Future: Annex 1, Summary of Proposed Legal Principles for Environmental Protection and Sustainable Development Adopted by the WCED Experts Group on Environmental Law. Annex ini terdiri dari 4 bagian yaitu: (1) Prinsip umum, hak dan kewajiban; (2) Prinsip, Hak dan Kewajiban terkait Sumber Daya Alam Lintas Nasional dan Interferensi Lingkungan Hidup; (3) Kewajiban Negara; (4) Penyelesaian Sengketa secara Damai.

${ }^{30}$ Ernst Ulrich von Weizsacker, Earth Politics, (New Jersey: Zed Books, 1994), hlm. 1-4.

${ }^{31}$ UU No. 6 Tahun 1994 tentang Pengesahan United Nations Framework Convention On Climate Change (Konvensi Kerangka Kerja Perserikatan Bangsa Bangsa Mengenai Perubahan Iklim), Lembaran Negara Tahun 1994 No. 42, Tambahan Lembaran Negara No. 3557 
Tahun 1994. ${ }^{32}$ Selain itu, Earth Summit juga menghasilkan Agenda 21, yang merupakan perincian lebih detail mengenai program-program pembangunan berkelanjutan menjelang Abad 21.

Salah satu hal yang cukup mempengaruhi gerakan pembaruan hukum lingkungan dari Deklarasi Rio adalah Prinsip 10, yang kemudian dikenal sebagai 3 akses, yaitu akses informasi, akses partisipasi, dan akses keadilan. ${ }^{33}$ Konsep tiga akses ini menjadi penting karena meletakkan sebuah konsep yang vital baik untuk pengelolaan lingkungan hidup yang efektif dan juga untuk tata kelola yang demokratis - untuk pertama kalinya dalam skala global. Di mana semenjak itu komunitas internasional bergerak ke titik di mana aturan normatif dari Prinsip 10 haruslah dituangkan dalam bentuk yang mengikat secara hukum. ${ }^{34}$

Ratifikasi WTO Agreement dan penandatangan Letter of Intent dengan International Monetary Fund (IMF) dan lembaga keuangan dunia lainnya ${ }^{35}$ memberikan pengaruh signifikan dalam pembentukan perundang-undangan Indonesia dalam bidang pengelolaan SDA. Mengikuti restrukturisasi dan perbaikan tata kelola ekonomi Indonesia yang merupakan komponen utama persyaratan IMF, pada 1999-2000, bersamaan dengan tumbangnya Orde Baru, dilakukan pula Structural Adjustment Program (SAP), ${ }^{36}$ yang salah satu

32 UU Nomor 5 Tahun 1994 Tentang Pengesahan United Nations Convention On Biological Diversity (Konvensi Perserikatan Bangsa-Bangsa Mengenai Keanekaragaman Hayati), Lembaran Negara Republik Indonesia Tahun 1994 Nomor 41, Tambahan Lembaran Negara Republik Indonesia Nomor 3556

33 Sebagai soft law, Prinsip 10 memiliki kekuatan hukum dengan adopsi ke dalam legislasi nasional negara-negara atau dengan penunjukan prinsip ini oleh dokumen-dokumen hardlaw (misalnya Konvensi, dll). Implementasi Prinsip 10 dalam level nasional telah mencatat banyak tantangan di berbagai negara, terutama terkait dengan kurangnya kapasitas (keterampilan maupun pengetahuan) dan sumber daya. Oleh karena itu, dalam World Summit, Sustainable Development Plan of Implementation menyatakan bahwa penerapan prinsip ini dalam level nasional harus mempertimbangkan secara penuh Prinsip 5, 7 (common but differentiated responsibility), dan 11 Deklarasi Rio. Lih: Lal Kurukulasuriya dan Nicholas A. Robinson, Training Manual on International Environmental Law, (UNEP/Earthprint, 2006)

${ }^{34}$ United Nations Audiovisual Library of International Law: Declaration of the UN Conference on the Human Environment and Environment and Development. Lihat: http://untreaty.un.org/cod/avl/ha/dunche/dunche.html

35 Christopher Barr, et.al. Tata Kelola Keuangan dan Dana Reboisasi selama Periode Soeharto dan Pasca Soeharto, 1989-2009: Suatu Analisis Ekonomi Politik tentang Pembelajaran untuk REDD+, (Bogor: CIFOR Publishing, 2011.

36 International Monetary Fund (IMF), Memorandum of Economic and Financial Policies Medium-Term Strategy and Policies for 1999/2000 and 2000, Sumber: http://www.imf.org/external/np/loi/2000/idn/01/ 
dampaknya adalah intervensi pembentukan perundang-undangan ekonomi dan SDA. Pengaruh intervensi dari SAP dalam sektor SDA tampak dalam deregulasi sektor ketenagalistrikan ${ }^{37}$ dan minyak dan gas bumi ${ }^{38}$ yang mengamanatkan privatisasi sektor energi, serta dalam pengelolaan sumber daya air. Di antaranya, dalam Pasal 28 ayat (2) dan (3) UU Migas, harga minyak diserahkan kepada mekanisme pasar. Pasal ini dibatalkan oleh Putusan MK karena dianggap tidak sesuai dengan Pasal 33 UUD 1945. ${ }^{39}$

Di sisi lain, perhatian internasional mengenai pemanasan global merupakan unsur yang cukup banyak mewarnai arah pembangunan hukum lingkungan internasional terutama pasca didirikannya Intergovernmental Panel on Climate Change (IPCC) pada 1988. ${ }^{40}$ Konferensi Rio 1992 menghasilkan UN Framework Convention on Climate Change (UNFCCC), dan dalam laporan kedua IPCC pada 1995 dinyatakan tanda-tanda pemanasan efek rumah kaca yang disebabkan manusia serta bahwa pemanasan serius diperkirakan akan terjadi abad selanjutnya. Salah satu peristiwa internasional yang mempengaruhi hukum lingkungan Indonesia secara signifikan adalah COP 13 UNFCCC yang diselenggarakan di Bali pada tahun 2007, di mana negaranegara mengadopsi Bali Road Map, yang memuat seperangkat keputusan yang mewakili berbagai jalur yang dianggap merupakan kunci untuk mencapai kesepakatan global perubahan iklim. ${ }^{41}$ Dalam Bali Action Plan, Indonesia berkomitmen untuk mereduksi emisi sebanyak $26 \%$ dari skenario business as

37 UU No. 30 Tahun 2009 tentang Ketenagalistrikan mengakomodir butir 77 dari Letter of Intent antara Pemerintah RI dengan IMF. Lih: Ibid.

38 UU No. 22 Tahun 2001 tentang Minyak dan Gas Bumi mengakomodir butir 80 dari LoI RI - IMF. Lih: Ibid. Dalam siding paripurna pembahasannya, terdapat 12 anggota dewan yang menyatakan minderheidsnota dengan alasan UU Migas bertentangan dengan Pasal 33 UUD 1945. Lih: M. Kholid Syeirazi, Di Bawah Bendera Asing: Liberalisasi Industri Migas di Indonesia, (Jakarta: LP3ES, 2009), hlm. 3

39 Putusan Mahkamah Konstitusi atas Perkara Register No. 002/PUU-I/2003, diajukan oleh APHI, PBHI, Yayasan 324, SNB dan Serikat Pekerja Karyawan Pertamina. Selain Pasal 28 ayat (2) dan (3), MK juga merevisi sebagian isi pasal 12 ayat (3) dan pasal 22 ayat (1) UU Migas.

${ }^{40}$ Konferensi bersama UNEP/WMO/ICSU mengenai "Assessment of the Role of Carbon Dioxide and Other Greenhouse Gases in Cliamte Variations and Associated Impacts" yang memperkirakan kebenaran saintifik dari pemanasan global diadakan pada 1985. Pada 1988, Inter-governmental Panel on Climate Change (IPCC) didirikan dan semenjak itu, pemanasan global telah menjadi isu yang diterima dalam hukum lingkungan. Sumber: IPCC Website, http://www.ipcc.ch/publications_and_data/publications_and_data_reports.shtml\#1

41 UNFCCC Website, Bali Climate Change Conference, December 2007. Sumber: https://unfccc.int/meetings/bali_dec_2007/meeting/6319.php 
usual (BAU) pada 2020, dengan usaha sendiri, dan $41 \%$ dengan bantuan internasional.

Pasca UNFCCC ke-13 yang menghasilkan Bali Action Plan, pertama kalinya secara resmi istilah REDD diperkenalkan dalam forum resmi internasioanl. Sebelumnya, pemerintah Indonesia menegaskan komitmennya untuk menurunkan gas rumah kaca sebesar $26 \%$ dengan kemampuan sendiri dan 41\% dengan dukungan internasional dalam forum G-20 di Pittsburgh, AS, pada tahun 2009. Komitmen besar itulah yang menarik perhatian komunitas internasional, di mana Indonesia mengawali keterlibatannya dalam perdagangan karbon dengan Letter of Intent antara pemerintah Indonesia dengan Norwegia dalam rangka penurunan emisi Gas Rumah Kaca dari pencegahan deforestasi dan degradasi hutan. Dengan masuknya Norwegia sebagai donor, maka capaian komitmen Indonesia dalam reduksi emisi menjadi $41 \%$, yang sempat menjadi kontroversi mengingat proporsionalitas dana bantuan Norwegia dibandingkan dengan komitmen reduksi. ${ }^{42}$ Dalam hal ini, Satgas REDD+ tidak dimaknai sebagai semata-mata implementasi dari LoI tersebut, akan tetapi sebagai bentuk komitmen Indonesia dalam tata kelola lingkungan dunia serta aspirasi masyarakat sipil yang menginginkan perbaikan tata kelola hutan dan gambut.

\subsection{Perkembangan Kebijakan dan Peraturan Lingkungan Hidup di Indonesia}

Awal perkembangan hukum lingkungan Indonesia terlihat dalam Garisgaris Besar Haluan Negara 1973-1978 yang mulai mengakomodir perlunya perlindungan lingkungan dalam melaksanakan pembangunan. ${ }^{43}$ Di waktu ini, konsep awal RUU tentang Lingkungan Hidup mulai dirumuskan oleh Panitia Nasional Perumus Kebijakan di Bidang Lingkungan Hidup yang menghasilkan

42 Norwegia memberikan kontribusi sebesar USD 1 Milyar (dengan kurs tukar 6 NOK/USD) untuk membantu Indonesia dalam penyiapan institusi dan peraturan-peraturan untuk mengimplementasikan skema REDD+ Lih: Letter of Intent of Republic Indonesia and Norwegia Government, on "Cooperation on Reducing Greenhouse Gas Emissions from Deforestation and Forest Degradation". Sumber: http://www.regjeringen.no/upload/SMK/Vedlegg/2010/Indonesia_avtale.pdf

43 Bab III Pola Umum Pembangunan Jangka Panjang GBHN 1973-1978 
rumuskan program kebijaksanaan lingkungan hidup sebagaimana tertuang dalam Butir 10 Bab II GBHN 1973-1978 dan Bab 4 Repelita II.44

Pada 1978, Indonesia untuk pertama kalinya secara khusus mengakomodir perlindungan lingkungan hidup dalam cabang eksekutif dengan didirikannya Kementerian Negara Pengawasan Pembangunan dan Lingkungan Hidup. ${ }^{45}$ Emil Salim bertindak sebagai Menteri yang bertanggung jawab atas kementerian ini (selanjutnya disebut "Men-PPLH"). Dalam tahuntahun ini, Emil Salim melibatkan kelompok masyarakat sipil yang dikenal sebagai Kelompok 10 Pengembangan Lingkungan Hidup dalam KLH, di antaranya terdiri dari Erna Witoelar, George Junus, Nasihin Hasan, Bedjo Rahardjo, Dr. Meizar. Selain itu, di berbagai perguruan tinggi didirikan pula Pusat Studi Lingkungan (PSL), dari mana berbagai diskursus dan ide pengelolaan dan perlindungan lingkungan hidup muncul. Selain itu, keterlibatan Emil Salim dalam Bruntland Commission turut berkontribusi dalam pengembangan partisipasi dalam pengambilan keputusan lingkungan hidup. 46

Tahun 1982 merupakan tahun monumental bagi hukum lingkungan Indonesia, dengan disahkannya Undang-undang No. 4 Tahun 1982 tentang Ketentuan-ketentuan Pokok Pengelolaan Lingkungan Hidup ${ }^{47}$ yang merupakan peraturan perundang-undangan pertama yang secara komprehensif mengatur mengenai pengelolaan lingkungan hidup sebagai UU payung (umbrella act) bagi

44 Selain Keppres No. 16 Tahun 1972 yang mendasari pembentukan panitia ini, penting pula Keppres No. 27 Tahun 1975 yang mendasari pembentukan Panitia Inventarisasi dan Evaluasi Kekayaan Alam. Kementerian Lingkungan Hidup, Sejarah Kementerian Lingkungan Hidup, Sumber: http:/ / www.menlh.go.id/tentang-kami/sejarah-klh/

45 Keppres No. 28 Tahun 1978 jo. Keppres No. 35 Tahun 1978 mendasari pengangkatan Menteri Negara Pengawasan Pembangunan dan Lingkungan Hidup (Men-PPLH) dalam Kabinet Pembangunan III. Lih: Ibid.

46 Dalam sidang Bruntland Commission di Jakarta pada Maret 1985, untuk pertama kalinya diterapkan metode "forum dengar pendapat dan konsultasi publik" dengan berbagai kelompok masyarakat, pengusaha, akademisi, dan wakil pemerintah (multi-stakeholder forum). Selain menajadi model WECD selanjutnya, Emil Salim secara aktif mencoba untuk mereplikasikan metode ini dalam agenda-agenda KLH selanjutnya. Lih: Iwan J. Azis, et.al., Pembangunan Berkelanjutan: Peran dan Kontribusi Emil Salim, (Jakarta: Kepustakaan Populer Gramedia, 2010), hlm. 164

47 Penyusunan RUU Lingkungan Hidup telah dimulai pada tahun 1976 disertai persiapan pembentukan kelompok kerja hukum dan aparatur dalam pengelolaan sumberdaya alam dan lingkungan hidup. Pada periode ini beberapa peraturan perundangan yang terkait dengan lingkungan dihasilkan oleh berbagai instansi sektoral. Lih: Koesnadi Hardjasoemantri, Op. Cit., hlm. 60. 
perundang-undangan sektoral. ${ }^{48}$ Penting pula untuk dicatat bahwa penyusunan RUU ini sudah dimulai sejak 1976, bersamaan dengan permintaan pemerintah Amerika Serikat kepada USAID (US Aid for International Development) agar mulai melengkapi laporannya dengan analisa dampak lingkungan dari setiap proyek bantuan dan hibah mereka. ${ }^{49}$ Beberapa kasus penting yang menjadi landmark dalam perkembangan hukum lingkungan Indonesia mengikuti pengesahan UU 4/1982 ini.

Di tahun 1992, UU 24/1992 tentang Penataan Ruang50 disahkan, yang dalam praktek administrasinya menyebabkan polemik kewenangan KLH dalam penataan ruang. Pada era ini muncul cukup banyak regulasi mengenai lingkungan hidup, terutama pada 1994, di mana sebagai respon dari Konferensi Rio, Indonesia mengeluarkan beberapa produk UU untuk meratifikasi CBD, dan UNFCCC.

Di tahun 1997, dilakukan perubahan pertama terhadap UU 4/1982 yaitu dengan UU No. 23 Tahun 1997 tentang Pengelolaan Lingkungan Hidup (selanjutnya disebut "UU 23/1997"). ${ }^{51}$ Dalam UU ini, disediakan perangkat "stick" yang lebih banyak dan bervariasi, enforcement squad bernama Satuan Tugas Jaga Nusa didirikan untuk memperlancar penegakan hukum lingkungan. ${ }^{52}$ Class Action, atau gugatan perwakilan kelompok, pertama kali diterima di Indonesia melalui hukum lingkungan, yaitu dengan diakuinya gugatan perwakilan kelompok dalam UU 23/1997 ini, khususnya dalam penjelasan pasal 37 ayat (1) UU 23/1997.53 Akan tetapi, saat itu belum ada penjelasan / pengaturan lebih lanjut mengenai mekanisme class action, yang

48 Ibid.

49 Asian Development Bank, Environmental Planning and Management, Proceeding, 1986

50 Undang-Undang Nomor 24 Tahun 1992 tentang Penataan Ruang, Lembaran Negara Tahun 1992 Nomor 115, Tambahan Negara Nomor 3501

51 Undang-undang Nomor 10 Tahun 1997 tentang Ketenaganukliran, Lembaran Negara Republik Indonesia tahun 1997 Nomor 23, Tambahan Lembaran Negara Nomor 3676

52 Mas Achmad Santosa, “Epilog: Arah Pembaruan Menuju Pemberdayaan Hukum Lingkungan", Good Governance dan Hukum Lingkungan, (Jakarta: Penerbit ICEL, 2001), hlm. 316

53 Dalam pasal 37 ayat 1 UU No. 23 Tahun 1997 disebutkan bahwa masyarakat berhak mengajukan gugatan perwakilan ke pengadilan dan/atau melaporkan ke penegak hukum mengenai berbagai masalah lingkungan hidup yang merugikan perikehidupan masyarakat.Dalam penjelasan pasal 37 ayat (1) menyebutkan bahwa yang dimaksud hak mengajukan gugatan perwakilan pada ayat ini adalah hak kelompok kecil masyarakat untuk bertindak mewakili masyarakat dalam jumlah besar yang dirugikan atas dasar kesamaan permasalahan, fakta hukum, dan tuntutan yang ditimbulkan karena pencemaran dan/atau perusakan lingkungan hidup. 
kemudian diatur dalam PERMA 1/2002, salah satunya atas advokasi dari penggiat hukum lingkungan. ${ }^{54}$

Keseluruhan tatanan kenegaraan Indonesia maupun situasi politik mengalami perubahan besar dengan tumbangnya rezim Orde Baru pada tahun 1998, yang diikuti dengan reformasi birokrasi pada 1999-2000. Di era transisi ini, dimulailah desentralisasi dan otonomi daerah melalui UU No. 22 Tahun 1999 tentang Pemerintahan Daerah, ${ }^{55}$ yang bercita-cita mulia untuk menghapuskan kesenjangan pusat-daerah dengan memberikan otoritas pengelolaan SDA yang lebih besar kepada Pemerintah Daerah. ${ }^{56}$ Perbaikan pola penguasaan SDA ini diperkuat pula dalam TAP MPR IX/MPR/2001 tentang Pembaruan Agraria dan Pengelolaan Sumber Daya Alam, ${ }^{57}$ yang merupakan pernyataan politik bahwa Indonesia telah kegagalan pengelolaan SDA di masa lalu sehingga berbuah kerusakan lingkungan dan konflik - serta prinsip-prinsip yang harus menjadi landasan dalam peraturan perundang-undangan di masa depan. Akan tetapi, TAP MPR IX/2001 ini tenggelam dalam konstelasi politik dan berbagai perdebatan lainnya. ${ }^{58}$ Terlepas dari TAP IX/2001 dan intensi awal otonomi daerah, di masa mendatang kepentingan politik jangka pendek dan ambisi ekonomi daerah justru berdampak sangat luas terhadap pola eksploitasi sumber daya alam, yang ditengarai memperparah kondisi lingkungan hidup di Indonesia. ${ }^{59}$ Desentralisasi daerah yang diikuti dengan pelimpahan beberapa kewenangan pemberian perizinan pengelolaan SDA mendorong penerbitan

54 Peraturan Mahkamah Agung No. 1 Tahun 2002 tentang Hukum Acara Gugatan Perwakilan Kelompok

55 Undang-undang Nomor 22 Tahun 1999 tentang Pemerintahan Daerah (Lembaran Negara Republik Indonesia Tahun 1999 Nomor 60, Tambahan Lembaran Negara Nomor 3839). Kemudian UU ini digantikan dengan UU Nomor 32 Tahun 2004, yang kemudian diubah dengan UU Nomor 8 Tahun 2005 dan UU No. 12 Tahun 2008

56 Kementerian Lingkungan Hidup, “Mengukur Efektivitas 9 Tahun Desentralisasi Pengelolaan Lingkungan Hidup", dalam Sarasehan Review Pelaksanaan Otonomi Daerah Bidang Lingkungan Hidup, 17 Juni 2013. Sumber: http://www.menlh.go.id/review-pelaksanaan-otonomidaerah-bidang-lingkungan-hidup/\#sthash.dEjRLao4.dpuf

57 Indonesia, Majelis Permusyawaratan Rakyat (MPR-RI), ditetapkan pada 9 November 2001, disahkan dalam Rapat Ke-74 Panitia Ad Hoc II Bp Mpr Tanggal 19 Oktober 2001

58 Perkumpulan untuk Pembaharuan Hukum Berbasis Masyarakat dan Ekologis (HuMa), Catatan Diskusi Kembalinya TAP MPR ke dalam Tata Urutan Perundang-Undangan RI dan Konsekuensinya Terhadap Tap MPR No. IX Tahun 2001 tentang Pembaruan Agraria dan Pengelolaan Sumber Daya Alam, Jakarta, 27 Desember 2011

59 Mas Achmad Santosa, "Langkah-langkah Strategis Menuju Desentralisasi Pengelolaan Lingkungan Hidup yang Efektif", Op.Cit., hlm. 127 
izin-izin yang tidak terkendali dan menimbulkan dampak lingkungan yang serius. Deforestasi, degradasi hutan, serta kebakaran hutan mencapai puncaknya selama periode awal desentralisasi daerah.

Tahun 2007, Kementerian Lingkungan Hidup dengan UU No. 26 Tahun 2007 tentang Penataan Ruang ${ }^{60}$ dan SKB Menteri Dalam Negeri dan Menteri Lingkungan Hidup memasukkan pertimbangan lingkungan hidup dalam perencanaan kebijakan, rencana, dan program - secara spesifik dengan mengarusutamakan Kajian Lingkungan Hidup Strategis dalam revisi tata ruang wilayah.

Pada 2008, salah satu perjuangan masyarakat sipil dalam memperkuat akses atas informasi lingkungan membuahkan hasil dengan disahkannya UU No. 14 Tahun 2008 tentang Keterbukaan Informasi Publik. ${ }^{61}$ Di balik pengesahan UU ini tercatat beberapa organisasi lingkungan hidup yang mengawal, diantaranya ICEL. UU ini merupakan jaminan hukum hak atas informasi untuk mewujudkan keadilan lingkungan, yang merupakan perwujudan salah satu dari tiga akses yang dijamin oleh Prinsip 10 Deklarasi Rio.

Tahun 2009 kembali menjadi tahun yang penting dalam perkembangan hukum lingkungan Indonesia dengan dikeluarkannya UU No. 32 Tahun 2009 tentang Perlindungan dan Pengelolaan Lingkungan Hidup (selanjutnya disebut “UU 32/2009").62 Penyusunan UU 32/2009 ini, selain bertujuan menjawab kekurangan-kekurangan dalam pengaturan UU 23/1997,63 terutama

60 Undang-Undang Nomor 26 Tahun 2007 tentang Penataan Ruang, Lembaran Negara Republik Indonesia Tahun 2007 Nomor 68; Tambahan Lembaran Negara Republik Indonesia Nomor 4725

61 Undang-Undang Nomor 14 Tahun 2008 tentang Keterbukaan Informasi Publik, Lembaran Negara Republik Indonesia Tahun 2008 Nomor 61, Tambahan Lembaran Negara Republik Indonesia Nomor 4846

62 Undang-Undang Nomor 32 Tahun 2009 tentang Perlindungan dan Pengelolaan Lingkungan Hidup, Lembaran Negara Republik Indonesia Tahun 2009 Nomor 140, Tambahan Lembaran Negara Republik Indonesia Nomor 5059

${ }^{63}$ Naskah Akademis UU 32/2009 mengidentifikasi beberapa kelemahan dalam UU 23/1997, yaitu: (1) Lemahnya prinsip demokrasi dan desentralisasi; (2) Lemahnya pengaturan tentang kewenangan kelembagaan institusi lingkungan hidup; (3) Lemahnya perumusan tentang analisis mengenai dampak lingkungan hidup (AMDAL); (4) Lemahnya perumusan tentang sanksi administrasi; (5) Lemahnya perumusan tentang penyelesaian sengketa lingkungan hidup melalui pengadilan; (6) Ketidakjelasan perumusan tentang asas subsidiaritas; (7) Lemahnya kewenangan pejabat penyidik pengawai negeri sipil (PPNS) lingkungan hidup; (8) Lemahnya perumusan delik pidana lingkungan; (9) Ketidakpaduserasian antara UU No. 23 Tahun 1997 dengan beberapa UU, yaitu UU No. 26 
dilatarbelakangi adaptasi terhadap desentralisasi. Selain itu, UU ini juga mencoba untuk mengakomodir aspirasi yang ingin dituangkan kelompok akademisi dan masyarakat sipil untuk mengundangkan UU Pengelolaan Sumber Daya Alam (UU PSDA) ke dalam satu UU mengenai perlindungan dan pengelolaan lingkungan hidup. ${ }^{64}$ UU ini kembali mengakomodir konsepkonsep baru dalam perlindungan maupun pengelolaan lingkungan, seperti Anti-SLAPP (Strategic Lawsuit Against Public Participation), instrumen ekonomi lingkungan hidup - baik yang bersifat sukarela maupun wajib, inkorporasi aspek perencanaan melalui Kajian Lingkungan Hidup Strategis (KLHS) dan Rencana Pengelolaan dan Perlindungan Lingkungan Hidup (RPPLH), pengaturan mengenai perubahan iklim, dan perizinan lingkungan. Adanya ketentuan Anti-SLAPP dalam UU No. 32 Tahun 2009 memberikan perlindungan bagi setiap orang yang memperjuangkan hak atas lingkungan hidup agar tidak dituntut secara pidana ataupun digugat secara perdata. ${ }^{65}$ Ketentuan ini memperkuat jaminan partisipasi publik dalam pengelolaan lingkungan hidup dan SDA, terutama melindungi para aktivis (termasuk saksi dan ahli) dari tindakan pembalasan melalui lembaga peradilan oleh pihak lawan. ${ }^{66}$

Pada 2012, salah satu inisiatif masyarakat sipil yang diprakarsai ICEL, 'menghijaukan' lembaga peradilan melalui gagasan Green Bench Indonesia, mendapatkan legitimasi positif dengan SK Ketua Mahkamah Agung tentang

Tahun 2007 tentang Penataan Ruang dan UU No. 32 Tahun 2004 tentang Pemerintahan Daerah; serta (10) Belum diadopsinya prinsip-prinsip internasional dalam pengelolaan lingkungan hidup. Lih: Kementerian Lingkungan Hidup, Draft 1.1. Naskah Akademis Perubahan Undang-undang No. 23 Tahun 1997 tentang Pengelolaan Lingkungan Hidup, (Jakarta: 2009), hlm. 6-16.

${ }^{64}$ Mas Achmad Santosa, "Pokok-pokok Pemikiran Bagi Penyempurnan UU No. 23 Tahun 2009 tentang Pengelolaan Lingkungan Hidup", Op.Cit., hlm. 178

${ }^{65}$ Pasal 66 UUPPLH, "Setiap orang yang memperjuangkan hak atas lingkungan hidup yang baik dan sehat tidak dapat dituntut secara pidana maupun digugat secara perdata."

${ }^{66}$ Penjelasan Pasal 66 menyatakan "Ketentuan ini dimaksudkan untuk melindungi korban dan/atau pelapor yang menempuh cara hukum akibat pencemaran dan/atau perusakan lingkungan hidup;

Perlindungan ini dimaksudkan untuk mencegah tindakan pembalasan dari terlapor melalui pemidanaan dan/atau gugatan perdata dengan tetap memperhatikan kemandirian peradilan." 
Sertifikasi Hakim Lingkungan. ${ }^{67}$ Upaya menghijaukan pengadilan ini diawali dengan sejumlah kegiatan di forum internasional yang membahas mengenai perkembangan konsep green bench di berbagai belahan dunia. ICEL yang menjadi bagian dari E-Law dan Commission of Environmental Law (CEL) IUCN kerap kali mendiskusikannya dengan mitra global yaitu ahli-ahli hukum lingkungan di dunia. Konsolidasi gagasan green bench di Indonesia dilakukan selama kurang lebih 5 (lima) tahun yaitu selama penyelenggaraan pelatihan hukum lingkungan kepada ribuan hakim di hampir seluruh provinsi di Indonesia. Pelatihan hukum lingkungan ini dimotori oleh ICEL, Mahkamah Agung Republik Indonesia, dan pakar-pakar hukum lingkungan di Australia, yaitu Prof. Ben Boer, Prof. Rob Fowler, Prof. Brian Preston, dan ahli hukum lingkungan dari kalangan peradilan yaitu Justice Paul Stein dari Land and Environment Court New South Wales, Australia. Program pelatihan selama lima tahun ini didukung oleh Lembaga Kerja Sama Pembangunan Pemerintah Australia (AusAid). Manifestasi pengembangan kebijakan green bench oleh MA kemudian ditindaklanjuti oleh MA, Kementerian Lingkungan Hidup, dan ICEL sendiri. Sampai dengan tahun 2013, Mahkamah Agung dan Kementerian Lingkungan Hidup telah bekerjasama mengadakan pelatihan sertifikasi hakim lingkungan hidup yang telah melatih 154 hakim dari lingkungan Peradilan Umum maupun Peradilan Tata Usaha Negara.

Letter of Intent RI-Norwegia tentang Cooperation On Reducing Greenhouse Gas Emissions From Deforestation And Forest Degradation kemudian diikuti dengan penerbitan Inpres No. 10 Tahun 2011 tentang Penundaan Pemberian Izin Baru dan Penyempurnaan Tata Kelola Hutan Alam Primer dan Lahan Gambut, atau lebih dikenal sebagai Inpres Moratorium. Selanjutnya, Perpres No. 61 Tahun 2011 tentang Rencana Aksi Nasional Penurunan Emisi Gas Rumah Kaca (RAN-GRK) ${ }^{68}$ menjadi payung nasional strategi pencapaian komitmen Indonesia dalam menurunkan emisi GRK. REDD+ di Indonesia kemudian persiapannya dilakukan oleh Satuan Tugas REDD+ (Fase I, II) dan Pendirian Badan Pengelola REDD+). ${ }^{69}$ Dalam Fase I, tercapai penundaan

${ }^{67}$ Mahkamah Agung RI, Surat Keputusan Ketua Tim Pengarah Pelatihan Sertifikasi Hakim Lingkungan Hidup Nomor 39/Tuaka Bin/SK/IX/2013 tentang Hasil Pelatihan sertifikasi Hakim Lingkungan Hidup

68 Indonesia, Peraturan Presiden Republik Indonesia Nomor 61 Tahun 2011 Tentang Rencana Aksi Nasional Penurunan Emisi Gas Rumah Kaca, disahkan pada 20 September 2011

69 Mas Achmad Santosa dan Josi Khatarina, “REDD+ in Indonesia: Law and Governance Perspectives,", dalam Michael Faure dan Andri G. Wibisana (Ed.), Regulating Disasters, Climate Change, and Environmental Harm: Lessons from the Indonesia Experience, (Northampton: Edward Elgar, 2013), hlm. 164 - 206. 
pemberian izin baru pada hutan alam primer dan lahan gambut melalui Inpres No. 10 Tahun 2011. Dalam Fase II, dilakukan persiapan kelembagaan REDD+ yang dimulai dari pengembangan strategi nasional, strategi daerah, pengembangan konsep dan mekanisme monitoring, reporting, verification (MRV) pendanaan, peta jalan (mencakup harmonisasi peraturan perundan-undangan) serta pendirian Badan Pengelola REDD+ sendiri. Dari Fase II ini lahir Perpres No. 62 Tahun 2013 serta Inpres No. 6 Tahun 2013 tentang Perpanjangan Moratorium, penataan perizinan di 3 provinsi dan 11 kabupaten sebagai percontohan, pengembangan pendekatan penegakan hukum multi-door.70 Pembentukan Badan Pengelola REDD+ pada $2013^{71}$ merupakan salah satu kebijakan penting untuk mempercepat pelaksanaan komitmen Pemerintah untuk mengurangi gas rumah kaca yang dihasilkan dari deforestasi dan degradasi hutan.

Perkembangan lain yang mencerminkan kemajuan dalam partisipasi masyarakat sipil adalah terbitnya Keputusan MenLH No. 17 Tahun 2012 yang merupakan pedoman teknis perlibatan masyarakat dalam proses AMDAL dan Izin Lingkungan. ${ }^{72}$

\subsection{Landmark Cases dan Yurisprudensi}

Penerapan prinsip-prinsip hukum lingkungan dapat tercermin pula dalam putusan Pengadilan, bahkan terkadang sebelum peraturan formal mengatur secara eksplisit mengenai suatu konsep hukum tertentu. Sebagai negara yang tidak menganut stare decicis, ${ }^{73}$ putusan hakim yang layak diikuti

70 Ibid.

71 Sebelum pembentukan Badan Pelaksana REDD+, terlebih dulu dibentuk Satuan Tugas Persiapan REDD+ dengan Keppres No. 19/2010 (Fase I), yang dilanjutkan dengan Pembentukan Satgas REDD+ yang baru dengan Perpres 25/2011 (Fase II). Pada tahun 2013, Badan Pengelola REDD+ disahkan melalui Perpres No. 62 Tahun 2013.

72 Kementerian Lingkungan Hidup, Peraturan Menteri Lingkungan Hidup No. 17 Tahun 2012 tentang Pedoman Keterlibatan Masyarakat dalam Proses Analisis Mengenai Dampak Lingkungan dan Izin Lingkungan

73 Sebagai negara yang cenderung menganut civil law (sekalipun batasan civil dan common law semakin mengabur), Indonesia menganut doktrin yurisprudensi hanya untuk kasus tertentu yang mengandung basic reason sebagai prinsip hukum atas putusan yang bersangkutan. Hal ini berlaku apabila putusan yang dijatuhkan merupakan kasus yang berhubungan dengan perkembangan hukum, dan belum diatur dalam perundang-undangan sehiungga diperlukan penciptaan hukum baru - atau sudah diatur dalam perundang- 
sebagai preseden untuk selanjutnya menjadi yurisprudensi hendaklah memuat pertimbangan-pertimbangan hukum (legal reasoning) yang jitu dan meyakinkan semua pihak. ${ }^{74}$ Beberapa kasus yang diuraikan di bawah merupakan kasus yang tergolong terobosan hukum oleh hakim, sekalipun ketepatan pertimbangannya perlu ditelaah secara kritis.

Di tahun 1988, hukum lingkungan Indonesia mengalami perkembangan penting melalui yurisprudensi, dengan diakuinya hak gugat organisasi lingkungan hidup (NGO legal standing) ${ }^{75}$ untuk pertama kalinya dalam kasus WALHI v. PT Indorayon Utama. Legal standing ini diberikan sejalan dengan gagasan Christopher Stone dalam Should Tress Have Standing: Towards Legal Rights of Natural Objects sebagaimana dijelaskan dalam bagian Pengantar.

Putusan MA No. 1479K/Pid/1989 dalam kasus pabrik tahu Sidoardjo memiliki nilai penting dalam penggunaan bukti ilmiah dalam konteks penegakan hukum, yaitu dengan penerjemahan bukti ilmiah pencemaran ke dalam konteks pencemaran secara hukum. ${ }^{76}$ Kasus ini menjadi pembelajaran untuk mempergunakan pertimbangan hukum lingkungan secara lebih cermat. ${ }^{77}$

Digunakannya prinsip kehati-hatian (precautionary principle) yang merupakan soft law sebagai pertimbangan hakim dalam memutus kasus kapas transgenik $^{78}$ pada tahun 2003 merupakan pencapaian yang patut dipertimbangkan dalam perkembangan hukum lingkungan di Indonesia. Pada saat prinsip ini diterapkan, UU 23/1997 belum menginkorporasinya dalam peraturan perundang-undangan. Disinilah letak terobosan hukum PTUN yang mengakui penggunaan soft law dalam memutus perkara. Akan tetapi, sekalipun

undangan tetapi tidak sesuai lagi dengan nilai kesadaran perubahan sosial atau kondisi perekonomian. Lih: Yahya Harahap, "Pengembangan Yurisprudensi Tetap", disampaikan pada Seminar Hukum Nasional VI, Juli 1994, di Jakarta.

${ }^{74}$ Siti Sundari Rangkuti, “Beberapa Problematika Hukum Lingkungan”, Jurnal Hukum Lingkungan Tahun II No. 1/1995, (Jakarta: Penerbit ICEL)

75 Pengadilan Negeri Jakarta Pusat, Putusan Pengadilan Negeri Nomor 820/Pdt.G/1988.PN.JKT.PST. Untuk perkara lain di mana hak gugat lingkungan hidup ditegaskan kembali, lihat: PTUN Jakarta, WALHI v. PT Industri Pesawat Terbang Nusantara (putusan PTUN Jakarta Nomor 088/G/1994/PIUTANG/PTUN-JKT), WALHI v. Kejaksaan Negeri Mojokerto (1994), dan WALHI v. Presiden RI (1994)

${ }^{76}$ Terdapat perdebatan yang menarik dalam penerjemahan bukti-bukti, terkait dengan standar polusi (baku mutu ambient dan efluent) dari alat bukti dan bagaimana suatu pencemaran ditentukan. Lih: Siti Sundari Rangkuti, Op. Cit., hlm. 36

77 Putusan MA sendiri mendapatkan kritik yang cukup keras dari Prof. Siti Sundari, yang dianggap, di antaranya atas pelanggaran asas legalitas. Lih: Ibid.

${ }^{78}$ Putusan PTUN Jakarta No. No. 71/G.TUN/2001/PTUN-Jkt 
dalam kasus ini prinsip kehati-hatian diakui, interpretasi prinsip ini dikritik sebagai sangat sempit. Mengingat kontroversi dan ketidakpastian yang melingkupi dampak bioteknologi, setidaknya penerapan prinsip ini secara layak mensyaratkan AMDAL telah dilakukan. ${ }^{79}$

Di tahun 2004, Mahkamah Agung kembali membuat terobosan dengan penerapan strict liability dan prinsip kehati-hatian (precautionary principle) dalam kasus Mandalawangi, Jawa Barat, yaitu dengan Putusan Kasasi No. 1794K/Pdt/2004. Sekalipun ketepatan penerapan prinsip ini juga masih diperdebatkan, akan tetapi hal ini menunjukkan adanya pengakuan terhadap martabat lingkungan hidup yang berhak atas perlindungan dari ancaman serious or irreversible damage. Dalam teks asli Prinsip 15 Deklarasi Rio, perlindungan terhadap 'serious or irreversible damage' tersebut diberikan 'dengan tujuan melindungi lingkungan hidup ('in order to protect the environment') yang berdimensi ekosentrisme. ${ }^{80}$

\subsection{Inisiatif Masyarakat Sipil dan Pembaruan Hukum Lingkungan}

Perkembangan hukum lingkungan Indonesia tidak lepas dari beberapa aktor kunci yang rekam jejaknya mewarnai pengembangan diskursus keilmuan maupun praktek hukum lingkungan. Wahana Lingkungan Hidup Indonesia (WALHI) berdiri pada tahun 1980 sebagai organisasi masyarakat sipil pertama yang bergerak dalam bidang lingkungan hidup di Indonesia. ${ }^{81}$ Berawal dari Kelompok 10 Pembangunan Lingkungan Hidup (PLH), WALHI dibentuk untuk mewadahi ambisi gerakan lingkungan hidup yang lebih besar dan bersikap independen. ${ }^{82}$ Suatu hal yang cukup menarik bahwa inisiatif

79 David Nicholson, Environmental Dispute Resolution in Indonesia, Doktoral Thesis dari Universitas Leiden, 2005

80 Prinsip 15 Rio Declaration menyatakan, "In order to protect the environment, the precautionary approach shall be widely applied by States according to their capabilities. Where there are threats of serious or irreversible damage, lack of full scientific certainty shall not be used as a reason for postponing cost-effective measures to prevent environmental degradation."

${ }^{81}$ Sekarang WALHI berada di 28 propinsi dengan total 479 organisasi anggota dan 156 anggota individu (terhitung Desember 2011), berafiliasi di tingkat internasional dengan Friends of the Earth. Sumber: http://www.walhi.or.id/v3/index.php?option=com_content\& view $=$ article\&id $=89 \&$ Itemid $=59$

82 WALHI, Website Resmi, “WALHI: Arus Utama Gerakan Lingkungan”, Sumber: http:/ $/$ www.walhi.or.id/v3/index.php?option $=$ com_content\&view $=$ article\&id=108\&Itemid= $\underline{60}$ 
berdirinya WALHI diawali dengan ide dari beberapa tokoh yang dikenal luas pada saat itu, termasuk didukung oleh Menteri Lingkungan Hidup dan Kependudukan, Prof. Dr. Emil Salim. Pada awalnya, WALHI berfokus pada awareness raising pada masyarakat. ${ }^{83}$ Pada 1988, WALHI mulai melakukan advokasi-advokasi berdimensi antroposentris yang bertujuan untuk mewujudkan keadilan sosial melalui advokasi kasus dan kebijakan Negara. ${ }^{84}$ Dengan latar belakang para anggota presidiumnya yang sebagian berasal dari pegiat advokasi berdimensi sosial dan keadilan hukum, yang antara lain berasal dari Lembaga-lembaga Bantuan Hukum (LBH) di seluruh Indonesia, advokasi WALHI mulai dikenal lebih frontal dan menggunakan advokasi hukum melawan kekuasaan. ${ }^{85}$

Salah satu kasus yang monumental adalah pembelaan dalam kasus DAM / Bendungan Kedung Ombo pada tahun 1985 oleh YLBHI. Peristiwa ini muncul sebagai akibat dari kebijakan ekonomi dan pembangunan yang diistilahkan sebagai driven by donor, di mana World Bank dan Indonesia dalam kerangka hutang luar negeri bersepakat untuk membangun bendungan sebagai upaya pemenuhan kebutuhan energi listrik nasional. Peristiwa ini mendapatkan sorotan publik secara luas, dan merupakan salah satu landmark dalam membangkitkan keperdulian publik secara luas, termasuk akademisi dan ahli hukum, terhadap keterkaitan antara pembangunan ekonomi, hak asasi manusia, dan lingkungan hidup. Dalam pembelaan kasus Kedung Ombo ini, maka semakin kokoh sinergi antara aktivis gerakan lingkungan hidup dengan gerakan hukum dan hak asasi manusia. Perubahan pendekatan WALHI dari soft menjadi lebih struktural dan militan tak lepas dari pengaruh sosok presidium nasional yang sebagian terdiri dari aktivis-aktivis bantuan hukum, terutama Abdul Hakim Garuda Nusantara sebagai ketua YLBHI pada saat itu. Di masa itu, pengarusutamaan pendekatan politik hukum dalam gerakan lingkungan hidup semakin terlihat jelas.

83 WALHI menyebutnya dengan periode menggugah atau membangunkan kembali banyak pihak tentang pentingnya pelestarian lingkungan dan peran serta masyarakat untuk mewujudkan lingkungan hidup yang sehat dan lestari. Lih: Refleksi Umum 1980 -1992 dalam Laporan Kegiatan WALHI Periode 1989 - 1992

84 Advokasi WALHI yang pertama kali dilakukan yaitu menggugat sejumlah Kementerian dan Lembaga Pemerintah melalui gugatan perdata WALHI v. Indorayon. Lih: WALHI, Ibid.

85 Visi WALHI adalah terwujudnya suatu tatanan sosial, ekonomi, dan politik yang adil dan demokratis yang dapat menjamin hak-hak rakyat atas sumber-sumber kehidupan dan lingkungan hidup yang sehat. Sumber: WALHI, "Tentang WALHI", Sumber: http:/ / www.walhi.or.id/v3/index.php?option $=$ com_content\&view $=$ article\&id $=89 \& I t e m i d=5$ $\underline{9}$ 
Beberapa aktor kunci dalam pembaruan hukum lingkungan pada saat itu dan yang masih aktif sekarang ini tidak terlepas pula dari pengaruh para pendiri WALHI, seperti Erna Witoelar. Erna Witoelar memprakarsai beberapa program peningkatan kapasitas di bidang hukum lingkungan, dengan Canadian Environmental Law Association (CELA) dan Canadian Environmental Law and Policy (CELP) dalam kerangka kerja sama Pemerintah Indonesia dan Kanada (CIDA). Erna Witoelar pada saat itu mengirimkan salah seorang aktivis LBH untuk magang di CELA dan CELP tersebut, yaitu Mas Achmad Santosa. Dua tahun setelah itu, Emil Salim yang pada saat itu menjabat sebagai Menteri Kependudukan dan Lingkungan Hidup, Koesnadi Hardjasoemantri sebagai pakar hukum lingkungan dan Rektor Universitas Gadjah Mada, dan Erna Witoelar, serta Abdul Hakim Garuda Nusantara sebagai Ketua YLBHI dan Ketua Presidium WALHI mengembangkan program Master Hukum Lingkungan untuk perwakilan LSM. Pengiriman Mas Achmad Santosa dari YLBHI dan Arimbi Heroepoetri dari WALHI mengikuti program Master hukum lingkungan dimaksudkan untuk memperkuat gerakan hukum lingkungan di Indonesia.

Pada 1993, Indonesian Center for Environmental Law (ICEL) didirikan, dengan berakar pada arah gerakan hukum lingkungan yang dilakukan oleh LBH dan WALHI, yang menitikberatkan pada pembaruan kebijakan hukum di sektor perlindungan dan pengelolaan lingkungan hidup. ICEL memiliki kekhasan sebagai lembaga advokasi berbasiskan riset, dengan 'dua kaki' di dunia akademisi sekaligus aktivis gerakan. Program INSELA (IndonesiaNetherlands Study on Environmental Law and Administration) yang diprakarsai oleh Universitas Leiden, Belanda dan ICEL merupakan salah satu program yang memperkuat warna kajian dari ICEL dan memberi pengaruh pada perkembangan hukum lingkungan setelah itu. Perkembangan konsep tindak pidana korporasi (corporate criminal liability) dan strict liability diperkuat pada saat program INSELA berlangsung. Penguatan penegakan hukum administrasi yang dituangkan di dalam UU No. 32 Tahun 2009 juga didapat salah satunya dari pembelajaran selama program INSELA berlangsung.

Setelah reformasi menghasilkan sejumlah komitmen baru pasca 1998, ICEL menyadari pada saat itu diperlukan sejumlah instrumen hukum yang mampu memperkuat demokrasi dan konsep Negara hukum yang demokratis melalui gagasan pengembangan UU tentang kebebasan untuk memperoleh informasi (yang belakangan dikenal dengan UU Keterbukaan Informasi Publik, 'UU KIP'), UU tentang perlindungan saksi dan pelapor (whistleblower protection) dan UU yang mendorong transparansi dan pelibatan masyarakat dalam 
pembentukan peraturan perundang-undangan. Pada masa itu, ICEL mengkhususkan diri untuk secara konsisten memperjuangkan UU tentang memperoleh kebebasan informasi publik. Sedangkan, kedua UU lainnya, advokasi pembentukannya dikerjakan oleh organisasi-organisasi masyarakat sipil lainnya, antara lain LBH, PSHKI (Pusat Studi Kebijakan Hukum Indonesia), LEIP dan ICW. Sejak perjuangan menggulirkan gagasan pentingnya UU tentang kebebasan memperoleh informasi tahun 2000, ICEL juga mengembangkan gagasan yang disebut dengan access initiatives (tiga akses dalam pengelolaan lingkungan hidup) yang merupakan jaringan yang difasilitasi oleh World Resources Institute (WRI). Keterlibatan aktif ICEL dalam keterbukaan informasi dan tiga akses tersebut sampai dengan saat ini masih dilakukan oleh generasi-generasi berikutnya. Di sisi lain, sebagai prakarsa untuk mengembangkan peradilan yang bersih dan independen, ICEL ikut serta terlibat dengan prakarsa-prakarsa yang dilakukan oleh Lembaga Kajian dan Advokasi untuk Independensi Peradilan (LEIP) dan PSHKI. Bagi ICEL, gerakan hukum lingkungan di Indonesia tidak dapat dipisahkan dari gerakan penguatan demokrasi dan pembenahan sistem peradilan. Dengan demikian, gerakan hukum lingkungan yang didorong oleh ICEL adalah kombinasi antara penguatan demokrasi, penguatan rule of law, dan sustainable development.

\section{Melihat Kembali \\ Pencapaian Hukum Lingkungan Indonesia dalam Mewujudkan Tata Kelola Lingkungan yang Baik dalam Demokrasi}

Demokrasi dan rule of law merupakan prasyarat terlaksananya sustainable development. Idealnya, hukum lingkungan harus dapat menjembatani demokrasi konstitusional dengan rule of law. Peran hukum dalam pemenuhan hak konstitusional terkait dengan lingkungan hidup perlu diprioritaskan, dan hukum lingkungan seharusnya tidak dimaknai secara reduksionis dengan porsi yang lebih besar dalam pengaturan yang ditujukan mendorong ketaatan perusahaan semata. Visi gerakan pembaruan hukum lingkungan ini adalah untuk mengharmonisasikan ketiganya: demokrasi, rule of law, dan sustainable development - melalui check and balances oleh masyarakat sipil dan penegakan hukum. Partnership (kemitraan) antara semua pihak yang terkait, baik pemerintah, masyarakat sipil, maupun swasta, dan usaha-usaha kolaboratif menjadi suatu keharusan untuk mencapai harmonisasi ini.

Dari penjabaran mengenai inisiatif internasional, pengembangan hukum dan kebijakan nasional, serta landmark cases di atas, terlihat suatu benang merah 
bahwa dalam pembentukan hukum lingkungan Indonesia, telah terdapat berbagai pemikiran maupun legislasi yang bertujuan mengakomodir peran masyarakat sipil terutama dalam konteks pemenuhan hak atas lingkungan hidup yang baik dan sehat bagi manusia (shallow ecology). ${ }^{86}$ Sementara itu, dalam hal pemenuhan hak bagi lingkungan hidup itu sendiri (right of environment dalam konteks deep ecology), sekalipun telah ada pengakuan tertentu dalam legislasi (mis: Pasal 92 UUPPLH tentang legal standing NGO), 87 belum dapat dikatakan bahwa pengakuan hak lingkungan hidup sebagai subjek hukum telah menjadi suatu gagasan hukum yang benar-benar mapan di Indonesia. Sekalipun dalam UUPPLH telah diakui NGO Standing, namun hal tersebut masih belum serta merta dapat dikatakan sebagai manifestasi dari pengakuan nature rights atau pengejahwantahan konsep hukum Christopher Stone 'legal rights of the natural objects'.

Dalam konteks hak, hak atas lingkungan hidup yang sehat ini berhubungan erat pula dengan hak-hak lainnya, baik hak-hak subjektif yang bersifat substantif, misalnya hak atas kesehatan, hak atas air, hingga hak-hak masyarakat adat, maupun hak-hak prosedural yang kemudian dikenal sebagai hak tiga akses. ${ }^{88}$ Akan tetapi, jika hak-hak prosedural dalam UUPPLH masih berlandaskan pada hak atas lingkungan hidup yang baik dan sehat yang diberikan pada manusia, ${ }^{89}$ sebagaimana terlihat dalam uraian pada bagian sebelumnya, perwujudan tata kelola lingkungan yang baik dalam demokrasi di Indonesia, paling tidak secara normatif, telah melangkah lebih jauh daripada semata-mata pemenuhan lingkungan hidup yang sehat sebagai hak asasi manusia. Selain tercermin dalam pengakuan environmental standing, hal ini

86 Sebagaimana dijabarkan di atas terutama dalam Bagian 'Inisiatif Masyarakat Sipil', tampak bahwa intervensi yang dilakukan masyarakat sipil berhasil mempengaruhi berbagai macam regulasi dan kebijakan. Contoh hukum dan kebijakan lingkungan yang beriorientasi manusia adalah diadopsinya class action dalam hukum acara perdata Indonesia, bahkan hingga dibakukan dalam PERMA 1/2002 tentang Acara Gugatan Perwakilan Kelompok.

87 Sekalipun secara sekilas NGO Standing tampaknya mencerminkan teori Stone di mana NGO Lingkungan Hidup diakui kedudukan hukumnya sebagai 'environmental guardian' yang bahkan kini telah dinormakan dalam Pasal 92 UU 32/2009, akan tetapi dalam implementasi maupun secara telaah akademis masih diperlukan penegasan bahwa secara historis maupun secara praktis hak lingkungan hidup diakomodir dalam Pasal 92 ini.

88 Ibid.

89 Sebagaimana dipertegas dalam Pasal 65 UUPPLH, hak tiga akses ini muncul sebagai serangkaian ayat dengan Pasal 65 ayat (1) yang mempertegas bahwa "Setiap orang berhak atas lingkungan hidup yang baik dan sehat sebagai bagian dari hak asasi manusia." Selanjutnya, ayat (2) s.d. (4) mempertegas mengenai hak atas informasi, partisipasi dan keadilan, sehingga ketiga hal ini dapat dibaca sebagai suatu kesatuan. Lih: UU 32 Tahun 2009, Pasal 65. 
tercermin dari prinsip-prinsip hukum lingkungan yang melembaga baik melalui putusan-putusan hakim maupun penunjukan-penunjukan dalam instrumen hukum internasional maupun nasional, misalnya prinsip precautionary principle sebagaimana dijelaskan di atas. ${ }^{90}$

Dari segi konstitusi, Indonesia sendiri dapat dikategorikan dalam kategori komitmen sedang91 dalam hal konstitusionalisasi norma hukum lingkungan, dengan melihat pada: (1) Pengakuan subjective right dalam pengelolaan lingkungan sebagaimana diatur Pasal 28H ayat (1) UUD 1945; (2) Pengakuan bahwa elemen berwawasan lingkungan merupakan elemen penting dalam perekonomian nasional sebagaimana disebutkan dalam Pasal 33 ayat (4) UUD 1945.92 Artinya, konstitusi Indonesia masih mengakui sebatas hak-hak subjektif yang antroposentris, belum secara eksplisit menyatakan hak lingkungan hidup sebagai subjek hukum.

Jika melihat lebih jauh, yaitu regulasi dan kebijakan di tingkat sektoral, penormaan hukum lingkungan telah mengalami kemajuan yang signifikan dari segi kuantitas. Tidak hanya dengan UUPPLH yang mengusung berbagai konsepsi baru mulai dari hulu seperti RPPLH, Kajian Lingkungan Hidup Strategis, hingga instrumen ekonomi lingkungan, green budget (Anggaran

90 Salah satu catatan penting dalam UU 32/2009 adalah dinormakannya prinsipprinsip hukum lingkungan, baik yang telah melembaga dalam hukum lingkungan internasional maupun yang dirumuskan dalam konteks Indonesia, dalam Pasal 2 mengenai asas-asas hukum lingkungan, antara lain: (a) tanggung jawab negara; (b) kelestarian dan keberlanjutan; (c) keserasian dan keseimbangan; (d) keterpaduan; (e) manfaat; (f) kehatihatian; (g) keadilan; (h) ekoregion; (i) keanekaragaman hayati; (j) pencemar membayar; (k) partisipatif; (l) kearifan lokal; (m) tata kelola pemerintahan yang baik; dan (n) otonomi daerah.

${ }^{91}$ Komitmen tertinggi merupakan pengakuan yang lengkap atas hak hukum untuk alam (the right for the nature), hak-hak subjektif, kewajiban negara serta arah pembangunan. Sedangkan komitmen tinggi, hampir sama dengan kategori pertama minus the right for the nature. Pendekatan kategori kedua masih antroposentris. Komitmen memadai mengakui hakhak subjektif dan kewajiban negara dalam pasal-pasal khusus dan tersendii (tidak dicampur aduk dengan hak-hak lain). Komitmen sedang memberikan pengakuan hak subjektif tanpa mengakui kewajiban negara, namun memberikan arah pada pola pembangunan nasional. Hak subjektif dan arah pembangunan tidak diatur secara spesifik, tetapi digabung dengan hak-hak lainnya. Sedangkan pada kategori komitmen rendah, konstitusi sama sekali tidak mengakui norma hukum lingkungan (hak subjektif maupun kewajiban negara), maupun pengakuan pola dan arah pembangunan berkelanjutan. Lih: Mas Achmad Santosa, "Greener Constitution: Solusi Pengarusutamaan Pembangunan Berkelanjutan", dalam Iwan J. Azis, et.al. (Ed.), Pembangunan Berkelanjutan: Peran dan Kontribusi Emil Salim, (Jakarta: Gramedia, 2010), hlm. 125 - 150.

92 Mas Achmad Santosa, dalam pengantar Jimly Asshidiqqie, Green constitution: Nuansa Hijau Undang-Undang Dasar Negara Republik Indonesia Tahun 1945, (Jakarta: Rajawali Pers, 2009) 
Berbasis Lingkungan Hidup - 'ABLH'), peraturan perundang-undangan berbasis lingkungan hidup (green legislation) ${ }^{93}$ melainkan juga dalam berbagai Undang-undang lain, misalnya UU Keterbukaan Informasi Publik yang menjamin akses informasi lingkungan di semua sektor, yang mengintegrasikan AMDAL dan izin lingkungan sebagai bagian integral dari perizinan usaha, hingga yang sangat spesifik seperti ketentuan mengenai reklamasi tambang pada UU Pertambangan ${ }^{94}$ maupun ketentuan dana reboisasi hutan. ${ }^{95}$ Jika dipetakan per sektor, maka akan tampak bahwa telah begitu banyak pasalpasal dalam ketentuan sektoral yang merupakan perwujudan dari hak atas lingkungan hidup yang baik dan sehat, akses publik terhadap informasi, partisipasi dan keadilan; maupun yang lebih bersifat substantif. Sekalipun tidak terlepas dari kekurangan yang perlu terus dikaji secara kritis maupun diharmonisasikan antar peraturan perundang-undangan yang satu dengan yang lainnya.

Menilik kembali pada sejarah perundang-undangan Indonesia, telah begitu banyak produk perundang-undangan di bidang lingkungan hidup yang dibuat dengan tujuan menyempurnakan pengaturan sebelumnya. Akan tetapi perlu diperhatikan bahwa perumusan perundang-undangan tidak selalu dibarengi dengan implementasi yang baik. Pada tahun 2001, Emil Salim merefleksikan pemikirannya bahwa betapapun baik perumusan dan sistemnya, hukum lingkungan tidak bisa diterapkan jika tidak terdapat penjungkirbalikkan perimbangan kekuasan antara penguasa, pengusaha, dan masyarakat madani. ${ }^{96}$

Dalam konteks UU mengenai Pengelolaan Lingkungan Hidup sendiri, Michael Faure mencatat bahwa,

93 UUPPLH mengatur berbagai hal-hal baru, di antaranya: (1) adanya ketentuan mengenai perubahan iklim; (2) adanya KLHS dan RPPLH; (3) penguatan Amdal dan Izin Lingkungan; (4) penguatan dan penyempurnaan ketentuan hukum perdata, pidana dan administrasi; (5) diakomodirnya prinsip-prinsip hukum lingkungan; (6) ekoregion; (7) penguatan kelembagaan KLH dan PPNS. Lih: UU 32 Tahun 2009, Bagian Penjelasan.

${ }_{94}$ UU No. 4 Tahun 2009 dalam Pasal 96 c, dinyatakan bahwa salah satu kewajiban perusahaan pertambangan adalah melakukan reklamasi lahan dan hutan pasca pertambangan. Hal ini kemudian didetilkan dalam PP No. 78 tahun 2010 tentang Reklamasi dan Pasca Tambang.

95 Kewajiban ini ditegaskan dalam Pasal 35 UU No. 41 Tahun 1999 tentang Kehutanan bagi Pemegang IUPHHK, yang diturunkan dalam PP No. 35 Tahun 2002 tentang Dana Reboisasi.

96 Pengantar dari Emil Salim, hlm. vii. Dikutip kembali dalam Epilog: Arah Pembaruan Menuju Pemberdayaan Hukum Lingkungan, Lih: Mas Achmad Santosa, Op.Cit., (Jakarta: Penerbit ICEL, 2001), hlm. 316 
“Undang-undang Lingkungan Hidup Indonesia, baik UU 4/1982 maupun 1997, memiliki karakteristik dimana banyak provisi mendelegasikan kepada peraturan pelaksanaan lebih lanjut yang harus dapat menyediakan pengaturan yang lebih detail. Untuk sebagian besar, pihak yang berwenang tampaknya gagal untuk membuat peraturan-peraturan pelaksanaan ini sebagai hasil dari debat yang muncul mengenai revisi total dari UU 23/1997, bahkan sebelum UU ini telah terimplementasikans ecara efektif." 97

Hal yang sama terlihat pula dari UU 32/2009, yang mengakomodir berbagai perubahan yang sangat maju dalam rezim hukum lingkungan, akan tetapi terseok-seok memenuhi tuntutan ketentuan peralihannya yang mensyaratkan kesiapan peraturan pelaksanaan dalam waktu satu tahun semenjak pengesahan. ${ }^{98}$ Di penghujung tahun 2013, dari 21 mandat Peraturan Pemerintah dalam UU 32/2009, tercatat baru 1 (satu) PP yang telah menyelesaikan dua mandat sekaligus. ${ }^{99}$

Menarik untuk melihat kembali pemikiran Satjipto Rahardjo lima dekade lalu bahwa permasalahan dalam perkembangan hukum Indonesia dikarenakan belum mampunya bangsa ini mengajukan secara lengkap suatu gambar tentang hukum Indonesia di tengah-tengah perubahan sosial dan proses pembangunan yang terjadi. ${ }^{100}$ Beberapa penyebabnya adalah: (1) ketidaktepatan konsep dan doktrin yang digunakan; (2) penganutan terhadap model-model penyelenggaraan hukum dari Barat tanpa mengkritisinya dan menerimanya seolah-olah sebagai suatu model yang absolut-normatif, serta mempergunakannya sebagai ukuran absolut untuk menilai kehidupan hukum kita. ${ }^{101}$ Di samping ketiadaan peta jalan pengembangan peraturan perundangundangan untuk menyelamatkan lingkungan hidup dan kebijakan legislative

97 Michael Faure et.al., Environmental Law in Development: Lessons from the Indonesian Experience, (Cheltenham: Edward Elgar, 2006), hlm. 2

98 Lih: Pasal 126 UU 32/2009

99 Setidaknya terdapat 21 mandat materi yang diatur dalam Peraturan Pemerintah yang diamanatkan UU ini, akan tetapi hingga tulisan ini dibuat (akhir 2013), baru ada 2 (dua) mandat yang disahkan yaitu PP Izin Lingkungan. Lih: Indonesian Center for Environmental Law, Catatan Akhir Hukum Lingkungan 2013: Menegak Komitmen, Menunggak Implementasi, (Desember 2013), hlm. 2.

100 Satjipto Rahardjo, Pembangunan Hukum Nasional di Tengah-tengah Perubahan Sosial, Makalah disajikan dalam Pra Seminar Identitas HukumNasional yang diselenggarakan Fakultas Hukum Universitas Islam Indonesia, Yogyakarta, 19-21 Oktober 1987, hlm. 14.

101 Ibid. 
impact assessment, ${ }^{102}$ kajian komprehensif mengenai konsekuensi hukum yang muncul dari gagasan-gagasan baru yang diakomodir dalam perundangundangan yang mengikat, kerap kali tidak dilakukan dalam proses pembuatan peraturan baru.

Pada 2001, tinjauan menyeluruh terhadap keterkaitan antara tata kelola pemerintahan yang baik dengan pengelolaan lingkungan hidup dan SDA merupakan suatu mandat yang diperintahkan oleh TAP MPR No. IX Tahun 2001 tentang Pembaruan Agraria dan Pengelolaan SDA. Sampai saat ini, belum ada indikasi Kementerian dan Lembaga memprakarsai pelaksanaan dari mandat TAP MPR ini. Saat ini, dengan keberadaan UKP4 dan Badan REDD+, peta jalan pembaruan peraturan perundang-undangan di bidang SDA yang berbasis lahan telah menggunakan TAP MPR IX/2001 sebagai acuannya. Kementerian Hukum dan HAM saat ini menjadi koordinator dari pembahasan peta jalan tersebut yang akan mengundang $\mathrm{K} / \mathrm{L}$ terkait untuk merumuskan pembentukan peraturan perundang-undangan yang bersifat komprehensif.

Dalam kerangka hukum lingkungan di Indonesia, teridentifkasi empat permasalahan yang perlu untuk dibenahi: 1) Peraturan perundang-undangan memberikan diskresi terlalu besar kepada Pemerintah untuk melakukan konversi dan konsesi tanpa adanya perimbangan kekuasaan (checks and balances); 2) Peraturan perundang-undangan (di berbagai sektor memiliki banyak kekurangan, celah, tumpang tindih mengakibatkan praktek-praktek pengelolaan SDA-LH yang tidak berkelanjutan; 3) Peraturan perundangundangan tidak mendukung penerapan pengambilan keputusan yang mengutamakan penerapan tata kelola yang baik (misal dalam izin, program, dan pembuatan kebijakan); dan 4) Peraturan perundang-undangan tidak mendukung kelangsungan hidup masyarakat yang bergantung pada hutan, termasuk masyarakat adat. ${ }^{103}$

Sementara itu, potret penegakan hukum sendiri masih diwarnai: 1) Praktik korupsi; 2) Kurangnya kapasitas, dukungan ahli dan kemampuan penegak hukum menggunakan pendekatan multi-door; 3) Belum optimalnya

102 Sekalipun pada dasarnya merupakan cost-benefit analysis untuk menekan biaya inflasi dan biaya kontrol ketaatan, namun regulatory impact analysis (RIA) menganalisis berbagai konsekuensi yang muncul dari pasal-pasal sebuah regulasi yang akan terbit dan berlaku umum dalam proses pembuatannya, termasuk juga di beberapa Negara, misal Vietnam, mencakup penyesuaian dengan instrumen hukum lainnya. Lih: OECD, Regulatory Policies in OECD Countries: From Interventionism to Regulatory Governance, 2002, hlm. 45.

103 Mas Achmad Santosa, REDD+ Indonesia: Menuju Reformasi Tata Kelola Hutan dan Lahan Gambut, 19 Desember 2013 
pengawasan penaatan sebagai tulang punggung penegakan hukum administrasi; 4) Pertautan kepentinga politik dan bisnis yang berpotensi menghambat penegakan hukum yang efektif; 5) Walaupun peraturan perundang-undangan dapat menjerat pelaku fungsional, ketentuan pertanggungjawaban pidana korporasi jarang diterapkan. ${ }^{104}$

Untuk mengisi kekosongan mengenai keberadaan focal point dalam pemerintahan yang membenahi kebijakan hukum maupun pelaksanaannya (harmonisasi hukum), Satuan Tugas Kepresidenan mengenai Persiapan Kelembagaan REDD+ Jilid I dan Jilid II yang dipayungi oleh UKP4, melakukan akselerasi langkah-langkah pembenahan kebijakan hukum maupun penegakan hukum. Keberadaan Badan Pengelola REDD+ berdasarkan Perpres No. 62 Tahun 2013 dan keberadaan Lembaga Pencegahan dan Pengendalian Kerusakan Hutan berdasarkan UU No. 18 Tahun 2013 bersama-sama dengan KLH dan Kementerian Kehutanan dengan pengawasan dan dukungan dari masyarakat sipil dapat lebih mendorong gerakan hukum lingkungan di bidang sumber daya alam yang lebih memiliki keberpihakan terhadap dimensi ekosentrisme dan masyarakat marjinal.

Selain dapat melihat kembali terhadap peluang-peluang yang telah diuraikan di atas, peluang penegakan hukum lingkungan kedepannya didukung dengan hal-hal berikut: 1) Pendirian Satgas Khusus/BP REDD+ untuk memfasilitasi dan mengkoordinasikan penegakan hukum secara terpadu kasus terkait SDA-LH bekerjasama dengan Kepolisian, Kejaksaan, Kementerian Keuangan (Penyidik Pajak, Bea Cukai), Kementerian Kehutanan, KLH dan PPATK; 2) Hakim lingkungan untuk mengadili kasus terkait kejahatan SDALH; 3) Nota kesepahaman dan pedoman penanganan perkara tindak pidana SDA-LH di atas hutan dan lahan gambut dengan pendekatan multi-door antara Kemenhut, KLH, Kejaksaan, Kapolri, Kemenkeu dan PPATK; 4) Mulai ada pembulatan pemahaman tentang penerapan pertanggungjawaban pidana korporasi dan pengundangan UU 18/2013 tentang Pencegahan dan Pemberantasan Perusakan Hutan; dan 5) Penegakan hukum yang terintegrasi dan terkoordinasikan dengan baik dalam penanganan 21 kasus hutan, tambang dan kebun (menggunakan pertanggungjawaban korporasi dan multi-door)

Melalui penguatan integritas dan kapasitas lembaga-lembaga Pemerintahan di atas dan masyarakat sipil, termasuk Perguruan Tinggi, gerakan hukum lingkungan dapat memiliki pengaruh yang besar terhadap

104 Ibid. 
pembenahan kebijakan hukum dan pelaksanaan penegakan hukum untuk mewujudkan pembangunan berkelanjutan yang berbasiskan keadilan rakyat.

\section{Daftar Pustaka}

Barr, Christopher et.al. 2011. Tata Kelola Keuangan dan Dana Reboisasi selama Periode Soeharto dan Pasca Soeharto, 1989-2009: Suatu Analisis Ekonomi Politik tentang Pembelajaran untuk REDD+. Bogor: CIFOR Publishing.

Carson, Rachel. 1962. Silent Spring. Boston: Houghton Mifflin.

Danusaputro, St. Munadjat. 1981. Environmental Education and Training: Supporting Programme for the Development of Environmental Law. Jakarta: Binacipta.

Danusaputro, St. Munadjat. 1981. Hukum Lingkungan, Buku 1: Umum. Jakarta: Binacipta.

Danusaputro, St. Munadjat. 1984. Hukum lingkungan: Hukum Lingkungan Nusantara (Dalam Sistem Nasional dan Internasional), Buku V, Jilid 2. Bandung: Binacipta.

Forum for Democratic Reform. 2000. Democratization in Indonesia: An Assessment, (Stockholm: International Institute for Democracy and Electoral Assistance.

Hardjasoemantri, Koesnadi. 1987. Environmental Legislation in Indonesia. Yogyakarta, Indonesia: Gadjah Mada University Press.

Hardjasoemantri, Koesnadi. 2002. Hukum Tata Lingkungan Cet. ke-17, Ed. ke-7, Yogyakarta: Gajah Mada University Press.

Kementerian Lingkungan Hidup. Sejarah Kementerian Lingkungan Hidup. Sumber: http:/ / www.menlh.go.id/tentang-kami/sejarah-klh/

Kurukulasuriya, Lal dan Nicholas A. Robinson. Training Manual on International Environmental Law. UNEP/Earthprint.

Kusumaatmadja, Mochtar. 1995. Hukum, Masyarakat, dan Pembinaan Hukum Nasional. Bandung: Binacipta.

Kusumaatmadja, Mochtar. Fungsi dan Perkembangan Hukum dalam Pembangunan Nasional. Bandung: Bina Cipta.

Li, Quan dan Rafael Reuveny. 2006. “Democracy and Environmental Degradation". International Studies Quarterly (2006) 50, 935-956. 
Michael Faure et.al. 2006. Environmental Law in Development: Lessons from the Indonesian Experience. Cheltenham: Edward Elgar.

Nicholson, David. 2005. Environmental Dispute Resolution in Indonesia. Doktoral Thesis dari Universitas Leiden.

Pond, Recoe. 2006. Social Control Through Law. New Brunswick: Yale University Press

Rangkuti, Siti Sundari. 1995. "Beberapa Problematika Hukum Lingkungan”, Jurnal Hukum Lingkungan Tahun II No. 1/1995. Jakarta: Penerbit ICEL.

Rodriguez-Rivera, Luis E. 2001. "Is The Human Right To Environment Recognized Under International Law? It Depends on the Source," Colorado Journal of International Environmental Law and Policy, Vol. 12, (Winter 2001).

Salman, Otje. 1987. Ikhtisar Filsafat Hukum. Bandung: Armico.

Sands, Phillipe. 2003. Principles of International Environmental Law, 2nd Edition, Cambridge: Cambridge University Press.

Santosa, Mas Achmad. 2001. "Peran Reformasi Hukum dalam Mewujudkan Good Environmental Governance," Good Governance dan Hukum Lingkungan. Jakarta: ICEL.

Schrepfer, Susan R. 1989. "Establishing Administrative 'Standing': The Sierra Club and the Forest Service, 1897-1956", The Pacific Historical Review, Vol. 58, No. 1, 1989.

Shiva, Vandana. 2005. Earth Democracy: Justice, Sustainablity, and Peace. Cambridge: South End Press.

Sierra Club v. Morton 405 U.S. 727 (1972)

Stone, Christopher. 2010. Should Trees Have Standing? Law, Morality and the Environment, 3rd ed. London: Oxford University Press.

United Nations. 1972. Report of the U.N. Conference on the Human Environment, Declaration of the U.N. Conference on the Human Environment, U.N.Doc.A/CONF.

Von Weizsacker, Ernst Ulrich. 1994. Earth Politics. New Jersey: Zed Books. 